ISSN 2413-0877 Volume 1 (2015)

The 1st International Symposium on Aquatic Product Processing 2013

\title{
ANTICANCER AND ANTIAGGREGATION OF SEAWEED EXTRACT
}

\author{
Astuti Lamid1)*, Komari2) \\ 1)Centre of Applied Technology of Health and Clinical Epidemiology \\ 2) Centre of Biomedical and Basic Technology of Health \\ *e-mail: astuti4@yahoo.com
}

\begin{abstract}
Exploration of seaweed potential as sources of bioactive compounts were studied and found two type seaweeds from in Bali such as Caulerpa rasemosa and Gracillaria sp had potential as food suplements and prepared and consumed as food. These seaweeds were used as vegetables in daily diet as side dishes or can be consumed alone. Their bioactive components of these seaweeds were explored for degenerative diseases. Gracillaria sp or bukung hijau were extracted with different solvents and tested qualitatively for possible bioactive component. as anti cancer agents and anti platelet aggregations were performed in vitro. Using cancer cell of mice $(\mathrm{C} 3 \mathrm{H})$ and New Zealang Rabbits Platelet. The results showed that anti cancer growth of the extract was 7 th fraction of the extract with 78\% activities and LD50 was $0.1 \mathrm{ppm}$. The anti platelets aggregation optimum of the extract was $13.2 \%$. The formulation of food supplement from these seaweed may benefit to produce functional food related to health.
\end{abstract}

Keywords: seaweed extract, anti-cancer, anti platelet aggregation

\section{INTRODUCTION}

The problem of cardiovascular disease is one of the cause of death in Indonesia. (NIHRD 2008). This condition resulted in reduction quality human resources and also inreace of health cost of the community. This conditions was predicted to be more prevalece due to changing of life style, food patterrn consumtion and stress. Less exercise in daily life was practised by the community; food consumtion of community was more fatty and less dietary fiber; and more mobile community caused more stress. Biodiversity of marine resources must be explored to supply healthy supplement of the community. Previous study had been performed to explore the benefit of marine sources for bioactive component. These bioactive has been related to prevent or reduced risk of degenerartive diseased. (Quinn 1990; Komari 1997). Macroalgae are a source of biologically active phytochemicals such as carotenoids, phycobilins, fatty acids, polysaccharides, vitamins, sterols, tocopherol and also phycocyanins. Some of the compounds are known to have biological activity due to have potential beneficial use in healthcare. However, the chemical and nutritional composition of seaweeds depends on many factors, including species, geographical origin or area of cultivation, seasonal, environmental, and physiological variations, time of harvest, water temperature, and processing methods (lto and Hori 1989).

Marine macroalgae survai showed that some local knowledge is using seaweeds as food in some part of Indoesia. Mostly these seaweed can be produce for gelling agent ot agar, but another seaweed product was traditionaly prepared with simple technique as vegetables. The 
seaweeds such as cauliflower sp and gracillaria are cleaned with boiling water to remofve the sand and ather materials. The cleand seaweed is then serrved with salty fish extract (Komari 1997).

Previous study reviealed that some seaweeds having potential sources of bioactive compounds for degeneratif diseases. Caulerpa rasemosa is one of traditional seaweeds had been used as foods. The seaweeds is called bulung bunih has been studied having potential as sources of food supplement (Komari, 1997). Another seaweed bulung hijau belong to Gracillaria sp is also measured for anti cancer cell and anti platelet aggregation in vtro.

\section{MATERIAL AND METHODS}

\section{Material}

Seaweed used in this experiment is Gracillaria sp having washed with boiling water until the surfece of seweed clean. The clened seaweed was then extracted and the extract used to measure the anti agggregation of platelet obtained form New Zealand white blood and anticancaer agent using Cell line.

Extraction were conducted using solvents of ethanol, ethyl acetate, dichloromethane and methane. Based on qualitative test, the extract using dichloromethane was highets and contained tri terpenois. This extract was then tested for anti-aggregation of platelet and anticancer agent.

The extract were then performed in Thin Layer Chromatography with elution solvent was dichloromethan the fractions were collected for further measurement.

\section{Methods}

2.1 Measurement of citotoksisity of seaweed extract on cancer cell of mice (C3H).

The in viro determination was using cell line of mice. The extract was used cichloromethane and the solvent was vacuum evapotated and the dried extract was diluted in Fetal Bovine Serum (FBS). Cell cancer of mice (C3H) strain W.E. Heston National Cancer Institute, USA from Anatomy Pathology of University Indonesia cultured in the same solution at concentration of $0,00001,0,0001,0,001,0,01,0,1,1,0,10,0$ and 100,0 ppm. LD50 was obtained for 50\% of cancer cell inhibited at concentration of related extract.

After incubation time for 96 jam, cancer cell were counted and compared with control culture. Effect of residual solfent was also tested for effect on cencer cell of mice and no effect of the culture cancer cell. (Komari and Lamid (1997).

2.2 Measurement of Anti-aggregation Using cell latelet of New Zealand White

Determination of anti-aggregation of platelets of New Zealang White using PACS-4 equitment as describe by Komari (1997). The methods of level of platelet aggregation was describe by Method of Eguchi et al. (1991) and Born (1962). This determination measured of aggregetion og platelets of NZW as shown by PACKS-4 equipment. 
The seaweed extract was piltered using $0.02 \mathrm{~nm}$ filter to ensured no small particles was affet the measurement of aggregation of platelet. Rabbit bloob was centrifiges at $100 \mathrm{rpm}$ for 15 minutes Plasma Rich Platelet (PRP) was used as platelet aggregation and Plasma Poor Platelet was uased as control.

Adenosine $\mathrm{Di}$ Phosphat (ADP) is used as aggregation substance of platelet. The aggregation of the platelet is measured using changing of trnsmission of light responsed in equipment. The maximum response was the optimal effect of the plateted aggregation.

\section{RESULTS AND DISCUSSION}

As obtaied by previous study, seawedd used in this experimend belong Gracillaria sp or in Bali called Bulung hijau. This type of seaweed is locally prepared as vegetable mixed with salted fish extract. This vegetable can be consumed as vegetable alone or consumed with rice. (Komari 1997). The nutrient content of this vegetable was $152 \mathrm{Kcal}$ energy, 60,1g/100g water, protein $0,7 \mathrm{~g} / 100 \mathrm{~g}$, fat $0,5 \mathrm{~g} / 100 \mathrm{~g}$ and dietary fiber $0,7 \mathrm{~g} / 100 \mathrm{~g}$. Significant amount of micronutrient were iron, calcium, iron and beta carotene and low in fat and protein that the formula of seaweed could use as reduction of body weight in obesity (Komari and Lamid 1997).

\section{Effect of Seaweed Extract on Citotoxicity of Cancer Cell}

Extraction of this seaweeds was conducted using solvent of ethanol, athyl acetate, dichloromethane and metane and recovery of extract and its recovery were respectively $12.24 \%, 8.17 \%, 7.14 \%$ and $1.03 \%$. These bioactive activity to inhibit the growth of cancer cell oh mice was optimum observed in Dichloromethane extract of $74 \%$, ethyl acetat $58 \%$, ethanol $49 \%$ and methane $42 \%$ (Komari and Lamid 1997).

Eluation of extract from dichloromethane was colected for 12 fraction and the effect of these fraction on anti cancer cell of mice $(\mathrm{C} 3 \mathrm{H})$ can be shown in Table 1. The optimum effect of fraction on prevention of growth cancer cell was Fraction 7 with inhibition of $78 \%$ followed with other fractions below $76 \%$ (Table 1).

Determination of LD50 were measured an concentration of $100 \mathrm{ppm}$ to $0,00001 \mathrm{ppm}$ and result of this determination results in conecntration of $0,1 \mathrm{ppm}$ of dichloromethane having effect on 50\% inhibition of the cancer cell (Table 2) (Quin 1990; Ito and Hori 1989). 
Table 1. Anti Cancer Cell of Fraction of Dichloromethane

\begin{tabular}{ccc}
\hline Fraction of TLC & Rf Value & Anti Cancer Activity (\%) \\
\hline F1 & 0,95 & 41 \\
F2 & 0,91 & 49 \\
F3 & 0,84 & 59 \\
F4 & 0,77 & 75 \\
F5 & 0,71 & - \\
F6 & 0,60 & 69 \\
F7 & 0.52 & 78 \\
F8 & 0.46 & 57 \\
F9 & 0.39 & 56 \\
F10 & 0.32 & 51 \\
F1 & 0,25 & - \\
F1 & 0,11 & - \\
\hline
\end{tabular}

Table 2. Anti-Cancer Effect of Cancer cell of Mice in vitro

\begin{tabular}{cl}
\hline Extract Concentration & Level of Inhibition of Cancer cell Growth \\
\hline 100,0 & Very low \\
10,0 & Very low \\
1,0 & Close to $50 \%$ of control \\
0,1 & $50 \%$ of control \\
0,01 & Almost the same of Conrol \\
0,001 & The same as control \\
0,0001 & The same as control \\
0,00001 & The same as control \\
\hline
\end{tabular}

\section{Effect of Seaweed Extract on Platelet Aggregation}

Anti aggregration of platelet is relatively related to formation of atherosclerosis in human. The measurement of anti aggregation of dichloromethane extract was shown in Table 3. Most of the fraction having activity to inhibit the aggregation was less than $10 \%$ except fraction 7 had an effect of $13.2 \%$. Previous study showed that qualitative test of the faction having optimum effect on platelet aggregation and also anti cancaer cell growth was brownis green and the substance shloud be terpene. The terpene is anti oxidative compaound mostly extracted from plant. This inhibition activity was also previously reported in Caulerpa sp. (Komari 1997).and seaweed (Ito dan Hori 1989) (Table 3).

Table 3. Anti Aggregation of Platelet of Fraction of Dichloromethane

\begin{tabular}{cc}
\hline Fraction of TLC & Aggregation Inhibition Activity (\%) \\
\hline F1 & 4.2 \\
F2 & 5,1 \\
F3 & 1.8 \\
F4 & 6,2 \\
F5 & - \\
F6 & - \\
F7 & 13.2 \\
F8 & 5,7 \\
F9 & 1,3 \\
F10 & $2,5 \mathrm{~s}$ \\
F1 & - \\
F1 & - \\
\hline
\end{tabular}




\section{CONCLUSION}

Traditional vagetable of Bulung Hijau or Eushema sp resulted on optimum activity of the bioactive using dichloromethane solvent. This extracts was tested for anti agregation of platelet of New Zealang Whiteteh and cell-cancer of Mice (C3H). Platelet obtained from NZW mixed with the extract showed reduced aggregation level of $6,5 \%$ compared to control agregation of contol sample was $1,5 \%$. Measurement of LD50 of the extract was optimum at concentration of $0,1 \mathrm{ppm}$ to heve prevention of cell cancer growth protection.

This product can be imroved not onluy as cegetable fresh but also sivefferent produck to used as health product for community.

\section{REFERENCES}

Born GVR. 1962. Aggregation of blood platelets by adenosine diphosphate and its reversal. Nature 94: $927-929$

Eguchi Y, Sato Y, Sekizaki S, Ishikawa M. 1991. Studies on anti-atherosclerotic agents. Synthesis and inhibitory activities on platelet aggregation of 4-aryl derivatives of 7 ethoxy carboxyl-6,8- dimethyl 1(2H)-pthalazinone. Chem. Phar. Bull. 39 (8) 2009-2015

Ito K, Hori K 1989. Seaweed: Chemical composition and potential uses. Food Rev.Int.5:101144

Komari. 1997. Bioactive compounds of macroalgae for inhibitor of platelet aggregation. Presented at Indonesian Biotech. Conf. Jakarta, 17-19 June 1997

Komari, Lamid A. 1997. Exploration of bioactive component in some seaweeds related to degenerative diseases. Report NRDC 1997.

National Institute for Health Research and Development. 2008. Basic Health Research. Jakarta.

Quinn RJ. 1990. Bioactive molecules from marine organisms. Aust. J. Biotech. 4(4):246-250. 